\title{
Sciendo
}

Acta Veterinaria-Beograd 2018, 68 (3), 257-268

UDK: 636.7.09:616.981.71-036.22(497.11)

DOI: 10.2478 /acve-2018-0023

Research article

\section{MOLECULAR EVIDENCE OF Q FEVER AGENT COXIELLA BURNETII IN IXODID TICKS COLLECTED FROM STRAY DOGS IN BELGRADE (SERBIA)}

\author{
BOGUNOVIĆ Danica ${ }^{1 *}$, STEVIĆ Nataša², SIDI-BOUMEDINE Karim³, \\ MIŠIĆ Dušan ${ }^{4}$, TOMANOVIĆ Snežana ${ }^{5}$, KULIŠIĆ Zoran ${ }^{1}$, MAGAŠ Vladimir ${ }^{6}$, \\ RADOJIČIĆ Sonja ${ }^{2}$
}

\begin{abstract}
${ }^{1}$ Department of Parasitology, Faculty of Veterinary Medicine, University of Belgrade, Belgrade, Serbia; ${ }^{2}$ Department of Infectious Animals Diseases and Diseases of Bees, Faculty of Veterinary Medicine, University of Belgrade, Belgrade, Serbia; ${ }^{3}$ Anses, Sophia Antipolis Laboratory, Animal Q fever Unit, Sophia Antipolis, France; ${ }^{4}$ Department of Microbiology and Immunology, Faculty of Veterinary Medicine, University of Belgrade, Belgrade, Serbia; ${ }^{5}$ Department for Medical Entomology, Center of Excellence for Food and Vector-Borne Zoonoses, Institute for Medical Research, University of Belgrade, Belgrade, Serbia; 'Department of Reproduction, Fertility and Artificial Insemination, Faculty of Veterinary Medicine, University of Belgrade, Belgrade, Serbia
\end{abstract}

(Received 04 June, Accepted 13 July 2018)

Q fever is a zoonotic disease caused by Coxiella burnetii, a gram-negative coccobacillus, which has been detected in a wide range of animal species, mostly domestic ruminants, but also in wild mammals, pets, birds, reptiles, arthropods (especially ticks), as well as in humans. Although the exposure to domestic animals in rural areas is regarded as the most common cause of the disease in humans, recent studies have shown that the role of pets in the epidemiology of Q fever has been increasingly growing. Although the primary route of infection is inhalation, it is presumed that among animals the infection circulates through ticks and that they are responsible for heterospecific transmission, as well as spatial dispersion among vertebrates. The aim of this study was to determine the presence and prevalence of C. burnetii in ticks removed from stray dogs, as well as to examine the distribution of tick species parasitizing dogs on the territory of Belgrade city. A PCR protocol targeting IS1111 repetitive transposon-like region of C. burnetii was used for the detection of $C$. burnetii DNA in ticks and the results were confirmed by sequence analysis. In total, 316 ticks were collected from 51 stray dogs - 40 females $(78.43 \%)$ and 11 males $(21.57 \%)$. Three species of ticks were identified: Rbipicephalus sanguineus $(72.15 \%)$, Ixodes ricinus $(27.53 \%)$ and Dermacentor reticulatus $(0.32 \%)$. Out of 316 examined ticks, C. burnetii DNA was detected only in the brown dog tick R. sanguineus, with a total prevalence of $10.53 \%(24 / 228)$. The high prevalence of $C$. burnetii in R. sanguineus, which is primarily a dog tick, indicates the importance of dogs in the epidemiology of $\mathrm{Q}$ fever in the territory of Belgrade.

Key words: Belgrade, Coxiella burnetii, dogs, ticks, PCR

*Corresponding author: e-mail: danicab@vet.bg.ac.rs 


\section{INTRODUCTION}

Q fever is a zoonotic disease distributed worldwide, with the exception of Antarctica and New Zealand, caused by Coxiella burnetii. C. burnetii, a gram-negative coccobacillus, has been detected in a wide range of animal species, mostly domestic ruminants, but also in wild mammals, pets, birds, reptiles, arthropods (especially ticks), as well as in humans [1]. In nature, the bacterium occurs in two morphological forms - as a large cell variant (LCV) which is metabolically active intracellular form, and the small cell variant (SCV), which is an extracellular and metabolically inactive infectious form. SCV appears as a spore-like form, and it is extremely resistant to physical and chemical factors and can survive outside the host for prolonged periods of time [2,3]. Due to its exceptional resistance and stability in the external environment, as well as the possibility of aerosol dissemination, the Centers for Disease Control and Prevention have categorized $C$. burnetii as a category B Bioagent.

The most frequently reported source of human infection is the exposure to aerosols or animal products contaminated with infected domestic ruminants' excreta. Animals excrete $C$. burnetii in feces and urine, while gravid animals shed the agent through the placenta and birth products, which represent a significant source of environmental contamination [4-7]. The main route of human infection is inhalation of dust contaminated with excreta of infected animals [8]. Ingestion of raw milk as a source of human infection still remains a subject of controversy [6]. Although the exposure to domestic animals in rural areas is regarded as the most common cause of the disease in humans, recent studies have shown that the role of pets in the epidemiology of $\mathrm{Q}$ fever has been increasingly raised [9-11]. Dogs can be infected by means of ingestion of infected material (birth products), inhalation [5], but also through tick bites [12]. The disease in dogs is usually asymptomatic, but infection in pregnant bitches can lead to early death of pups [9].

More than 40 tick species can carry $C$. burnetii [1] and the agent can be found in the intestine, haemolymph, Malpighian vessels, salivary glands and ovaries of ticks. It can be transmitted transovarially and transstadially [1,13]. Considering the extremely high resistance of $C$. burnetii in the external environment, it is important to note that ticks can excrete large amounts of $C$. burnetii in feces - as high as $10^{10} \mathrm{bact} . / \mathrm{g}$ feces [14]. Although the primary route of infection is inhalation, it is presumed that among animals the infection circulates through ticks and that they are responsible for heterospecific transmission, as well as spatial dispersion among vertebrates $[15,16]$.

The aim of this study was to determine the presence and prevalence of C. burnetii in ticks removed from stray dogs, as well as to examine the distribution of tick species parasitizing dogs on the territory of Belgrade city. This population of dogs is important for examination because these animals are completely unprotected with ectoantiparasitics, they do not receive any chemoprophylaxis, and they move freely, which increases the chance of contact with potentially infected ticks. This way, stray dogs can carry the $\mathrm{Q}$ fever agent to new locations. By identifying the tick species 
parasitizing dogs, and the prevalence of C. burnetii-positive ticks, it is possible to define potential risk factors and the importance of ticks in the epidemiology of $\mathrm{Q}$ fever in stray dogs in Belgrade.

\section{MATERIAL AND METHODS}

\section{Ethics statement}

This research was approved by Veterinary Directorate of the Ministry of Agriculture, Forestry and Water Management of the Republic of Serbia, in accordance with the Animal Welfare Law, Law on General Administrative Procedure and Law on State Administration, Republic of Serbia, by the Decision no. 323-07-00364/2017-05/3.

\section{Sample collection}

Ticks were recovered from stray dogs, during the period from April to November, at the Faculty of Veterinary Medicine, University of Belgrade (Serbia). The animals were included in the program of sterilization and castration as part of the Strategy for solving the problem of stray dogs on the territory of Belgrade (Official Gazette of the City of Belgrade, No. 37/2011). Prior to surgery, a clinical examination of each animal was performed, and no animal showed symptoms that indicated any infectious disease. During the clinical examination, the body of each animal was also examined for the presence of ticks. Ticks were carefully removed from animals, using tweezers, and placed into glass vials with $70 \%$ ethanol. Each sample was adequately labelled, according to the animal from which it was removed, and kept at the temperature of $-20{ }^{\circ} \mathrm{C}$.

\section{Morphological identification of ticks}

Morphological identification of collected ticks was performed at the Laboratory for Parasitology at the Department of Parasitology at the Faculty of Veterinary Medicine, University of Belgrade. Identification was carried out by using a stereomicroscope (Carl Zeiss, Jena), at the 100x magnification. Ticks were classified into species and developmental stage according to standard taxonomic key [17].

\section{DNA extraction}

Prior to DNA extraction, individual ticks were rinsed in decreasing concentrations of ethanol $(70 \%, 50 \%$ and $30 \%)$. After the final wash in sterile distilled water, the ticks were left to air dry on sterile filter paper. Each tick was then placed in a separate 1.5 $\mathrm{ml}$ sterile plastic microtube. In the next step, sterile phosphate-buffer saline was added to each tube and the ticks were mechanically crushed and homogenized using a sterile metal rod. During the first phase, aliquots of homogenized ticks were pooled and each pool consisted of 3-10 ticks (depending on the sample size) in a final volume of $200 \mu \mathrm{l}$, according to species, developmental stage and the animal from which they 
were removed. The DNA was extracted in a final volume of $100 \mu \mathrm{l}$ using a commercial DNA extraction kit (GeneJET Genomic DNA Purification Kit, Fermentas, USA), according to the manufacturer's instructions. The extracted DNA was stored at -20 ${ }^{\circ} \mathrm{C}$. After obtaining positive tick pools, a DNA extraction was performed on each individual tick within the positive pools, as previously described.

\section{PCR}

A PCR protocol targeting IS1111 repetitive transposon-like region of C. burnetii [18] was used for the detection of $C$. burnetii DNA in ticks. For the PCR amplification, primers Trans-1 (5'-TAT GTA TCC ACC GTA GCC AGT C-3') and Trans-2 (5'-CCC AAC AAC ACC TCC TTA TTC-3') were used, yielding a specific fragment of $687 \mathrm{bp}$. The PCR reaction was performed on $10 \mu \mathrm{l}$ of each DNA sample, at a final volume of $25 \mu \mathrm{l}$. The final reaction mixture consisted of $2 \mu \mathrm{M}$ of each primer, $200 \mu \mathrm{M}$ of each dNTP, $3 \mathrm{mM} \mathrm{MgCl}_{2}$, and $0.5 \mathrm{U}$ of Taq DNA polymerase (Thermo Fisher Scientific, USA). DNA amplification was performed using the Mastercycler ${ }^{\circledR}$ ep Gradient S (Eppendorf, Germany) thermal cycler. The Touchdown PCR program included the following cycles: initial denaturation of DNA at $95{ }^{\circ} \mathrm{C}$ for $2 \mathrm{~min}$, followed by five cycles consisting of denaturation at $94{ }^{\circ} \mathrm{C}$ for $30^{\prime \prime}$, annealing from $66-61{ }^{\circ} \mathrm{C}$ (the temperature was reduced by $1^{\circ} \mathrm{C}$ in each subsequent cycle) for $1 \mathrm{~min}$, and extension at $72^{\circ} \mathrm{C}$ for $1 \mathrm{~min}$. After these five cycles, there were 35 cycles consisting of denaturation at $94{ }^{\circ} \mathrm{C}$ for $30^{\prime \prime}$, annealing at $61{ }^{\circ} \mathrm{C}$ for $30^{\prime \prime}$ and extension for $1 \mathrm{~min}$ at $72{ }^{\circ} \mathrm{C}$, and finale extension of $10 \mathrm{~min}$ at $72{ }^{\circ} \mathrm{C}$. Visualisation of PCR products was performed by using horizontal electrophoresis in 1\% agarose gel, at voltage of $100 \mathrm{~V}$ for $40 \mathrm{~min}$. Amplicons were stained with Midori Green DNA stain (Nippon Genetics Europe, $\mathrm{GmbH}$, Germany), visualized on UV transilluminator and photographed. Positive and negative controls were used in each PCR reaction. DNA extracted from the Phase I antigen of $C$. burnetii was used as a positive control and sterile distilled water was used as a negative control instead of DNA sample. In order to verify the repeatability of the results, PCR reactions were performed twice on each sample.

\section{Sequencing}

Purification of the PCR products was performed by using a commercial purification kit (QIAquick PCR Purification Kit, Qiagen, USA) according to the manufacturer's instructions. Sequencing was done in both directions using a commercial service (Macrogen, Europe). Obtained sequences were processed and analyzed by using BioEdit software, and sequence alignment was performed by using Clustal W [19]. The sequences were compared with analogue sequences deposited in the Gene Bank using BLAST.

\section{RESULTS}

In the current study, 316 ticks were collected from 51 stray dogs - 40 females $(78.43 \%)$ and 11 males (21.57\%). All dogs were mixed-breed, body weight ranging from 6 to 
$30 \mathrm{~kg}$. The number of ticks per animal was 1-42. All dogs were clinically healthy and sexually mature. In total, three species of ticks were identified: Rhipicephalus sanguineus, Ixodes ricinus and Dermacentor reticulatus. A total of 228 R. sanguineus (72.15\%), 87 of I. ricinus $(27.53 \%)$ and one D. reticulatus $(0.32 \%)$ samples were collected. Only two dogs had mixed infestation, one included both $I$. ricinus and $R$. sanguineus, and the other included both $I$. ricinus and $D$. reticulatus. Within the $R$. sanguineus species all three developmental stages were present - larvae, nymphs and adults (males and females) and within $I$. ricinus nymphs and adults (males and females). The distribution of developmental stages within species of collected ticks is presented in Table 1.

Table 1. Distribution of developmental stages within every tick species collected from dogs

\begin{tabular}{lccccc}
\hline \multirow{2}{*}{ Tick species } & Total & \multicolumn{4}{c}{ Developmental stages } \\
\cline { 3 - 6 } & $\mathbf{3 1 6}$ & female (\%) & male (\%) & nymph (\%) & larvae (\%) \\
\hline Rhipicephalus sanguineus & 228 & $40(17.54)$ & $51(22.37)$ & $130(57.02)$ & $7(3.07)$ \\
Ixodes ricinus & 87 & $33(37.93)$ & $44(50.57)$ & $10(11.49)$ & 0 \\
Dermacentor reticulatus & 1 & 0 & $1(100)$ & 0 & 0 \\
\hline
\end{tabular}

Out of 316 examined ticks, C. burnetii DNA was detected only in the brown dog tick R. sanguineus, with a total prevalence of $10.53 \%(24 / 228)$. The highest prevalence among collected ticks was detected in female ticks followed by nymphs and male ticks. In total, $30.00 \%(12 / 40)$ of female ticks, $5.88 \%$ (3/51) of male ticks and $6.92 \%$ of nymphs (9/130) were positive for C. burnetii. Animals with positive ticks harbored from two to 36 ticks in total, and no animal harbored all ticks that were positive for C. burnetii. Also, no positive ticks were detected in mixed infestations cases found on two dogs. Positive ticks originated from one male $\operatorname{dog}(1 / 11)$ and six female dogs (6/40). Distribution of positive ticks according to the dog from which they were removed is presented in Table 2.

Table 2. Distribution of ticks (positive and total samples) positive for presence of Coxiella burnetii DNA according to the dog from which they were removed

\begin{tabular}{lcccc}
\hline \multirow{2}{*}{ Animal } & \multicolumn{4}{c}{ Developmental stages of ticks } \\
\cline { 2 - 5 } & Female & Male & Nymph & Larva \\
\hline Dog 1 - Female & $5 / 5$ & $3 / 5$ & 0 & 0 \\
\hline Dog 2 - Male & $2 / 5$ & $0 / 1$ & 0 & 0 \\
Dog 3 - Female & $2 / 3$ & $0 / 1$ & 0 & 0 \\
Dog 4 - Female & $1 / 1$ & $0 / 1$ & 0 & 0 \\
Dog 5 - Female & $1 / 1$ & $0 / 5$ & 0 & 0 \\
Dog 6 - Female & $1 / 1$ & $0 / 1$ & 0 & 0 \\
Dog 7 - Female & 0 & 0 & $9 / 36$ & 0 \\
\hline Positive & 12 & 3 & 9 & 0 \\
\hline Total & \multicolumn{5}{c}{24} \\
\hline
\end{tabular}


Amplified specific sequences were visualized on 1\% agarose gel as a band of $\sim 687$ bp. Amplicons were purified and sequencing was performed in both directions. All analyzed sequences from this study were identical to each other. A representative nucleotide sequence was deposited in GenBank under accession No. MH394636. Nucleotide sequence analysis by BLAST was consistent with $C$. burnetii isolates deposited in GenBank with more than 99\% identity for IS1111 gene. Comparisons were also made with the published partial sequences of IS1111 region corresponding to Coxiella-like endosymbionts [20], which excluded the presence of endosymbionts in ticks (this study).

\section{DISCUSSION}

According to the currently available data and bibliography, there are no studies concerning the presence of $C$. burnetii in ticks parasitizing dogs in Serbia. In fact, only few researches have been conducted so far regarding the presence of $C$. burnetii in ixodid ticks in Serbia. In a previous study, conducted in six localities around Belgrade and one locality in Autonomous Province of Vojvodina, the presence of C. burnetii was revealed in questing I. ricinus $(17 / 27)$ and D. reticulatus $(2 / 10)$ ticks collected from vegetation but no ticks collected from animals were tested [21]. The results obtained in the current study showed that $R$. sanguineus ticks parasitizing stray dogs in Belgrade are infected with C. burnetii with total prevalence of $10.53 \%(24 / 228)$ and no positive ticks were found among $I$. ricinus and $D$. reticulatus ticks. It is possible that the disagreement of the results in these two studies is related to the origin of the samples. If we consider the fact that in our research tick samples were collected from free-roaming dogs, it is impossible to determine the origin of ticks that were recovered from these animals. Also, a recent study was carried out on ten localities in Serbia, regarding the molecular detection of various tick-borne pathogens in spleen samples of golden jackals, and ticks recovered from these animals. The presence of $C$. burnetii was not established neither in spleen samples or in ticks [22] .

In accordance with the results from the current study, research data from some endemic areas indicate the extremely low significance of $I$. ricinus in the maintenance of the $C$. burnetii cycle in nature. For example, after the biggest $Q$ fever epidemic in the last ten years that occurred in the Netherlands, the examination of 1891 questing I. ricinus ticks collected from vegetation in highly endemic areas did not show the presence of C. burnetii. The authors stated that the risk of acquiring infection from questing $I$. ricinus ticks on vegetation in these endemic areas is negligible [23]. Similar results were obtained in Luxembourg, where the absence of C. burnetii in 1500 questing I. ricinus ticks collected from vegetation was also recorded [24]. Also, in the studies conducted in endemic areas of southern Germany, which included 666 questing Dermacentor spp. adults, the presence of C. burnetii was not established [25]. Low prevalence of $3.08 \%$ were established in Slovakia and Hungary in questing I. ricinus ticks [26]. The studies conducted in the highly endemic areas of Basque County (Spain) also showed 
that I. ricinus has no significance in the epidemiology of $\mathrm{Q}$ fever, although it is the most abundant tick species in the region. Out of 1900 ticks collected from animals, no positive samples were established and the authors came to the conclusion that small rodents have the most important role in maintaining $Q$ fever cycle in this region $[27,28]$.

However, a high prevalence of $C$. burnetii that was established in the brown dog tick parasitizing stray dogs in the current study shows that the brown dog tick, which is primarily a dog parasite, may have a significant role in the cycle of $\mathrm{Q}$ fever among stray dogs in Belgrade. There is little data in the literature concerning the presence of $C$. burnetii in ticks collected specifically from stray dogs. In the city of Algiers (Algeria) the presence of $C$. burnetii was established in a spleen sample of one stray dog $(1 / 117)$ by using molecular methods. However, in ticks removed from the dogs, most of which belonged to the brown dog tick, C. burnetii DNA was not detected [29]. Similarly, although human Q fever infection related to the dogs had been previously described in Japan [11], later studies did not show the presence of C. burnetii in ticks removed from pet dogs in urban environments [30].

Yet, there are various examples that show the presence of C. burnetii in brown dog ticks recovered from different animal species and the significance of this tick species parasitizing animals in the epidemiology of Q fever. In the Canary Islands, which is an endemic area for $Q$ fever, authors examined the presence of C. burnetii in wild animals, ticks removed from wild and domestic animals and ticks from vegetation. The interesting fact is, although it is an endemic area, all ticks collected from the vegetation were negative, while the prevalence in ticks collected from animals was as high as $6.1 \%$. The brown dog tick was the most common species of tick found on domestic animals, and one positive sample originated from a domestic dog. The authors suggest that in this area $C$. burnetii circulate in the cycle which involves domestic animals, small rodents, lagomorphs, and ticks [31]. Whereas in central Spain the presence of $C$. burnetii was detected in both questing ticks $(7.7 \%)$ and in ticks collected from domestic and wild animals $(3.4 \%)$. All positive $R$. sanguineus samples originated from animals with a prevalence of $1.4 \%(2 / 146)$, out of which as many as 106 samples originated from pets. All R. sanguineus recovered from dogs were negative, which was explained by the fact that dogs originated from urban environments where $Q$ fever wasn't present [32]. Among the 1485 adult ticks removed from domestic and wild mammals in Sardinia, seven species were identified and most $R$. sanguineus tick originated from dogs $(92.3 \%)$. Out of 209 R. sanguineus pools, four positive were from dogs, and one from a goat [33]. Presence of $C$. burnetii was also established in $R$. sanguineus ticks collected from small ruminants in endemic areas in Cyprus [34] and further studies in Cyprus showed a significant correlation between seropositive ruminants and positive R. sanguineus and Hyalomma spp. ticks parasitizing them [35]. Recent studies conducted in Cyprus showed the presence of $C$. burnetii in ticks from wild animals on the entire island. Ten tick species were detected, and $28.7 \%$ of pooled samples (56/195) were positive for C. burnetii. Nine out of 15 R. sanguineus pools were positive for C. burnetii. 
Thus the authors underlined the importance of ticks in the epidemiology of Q fever on the whole island [36].

The high prevalence of $C$. burnetii in the brown dog tick obtained in this study is also significant because of endophilic behavior of this tick species and its ability of surviving inside premises (homes, kennels, animal shelters) where it can complete an entire life cycle in 2-3 months [37]. The transition and feeding of $R$. sanguineus males between dogs in cohabitation was previously described [38]. This type of behavior also accelerates transmission of pathogens during the next feeding $[37,38]$. This means that if the tick was introduced to the household on the dog, there would be a risk of acquiring infection for both dogs in cohabitation as well as for humans. In addition to the role of ticks as biological vectors for $C$. burnetii, risk analysis should consider the fact that ticks can excrete large amounts of $C$. burnetii in feces, creating an additional risk of infection due to the contamination of the animal's hair and the environment [14]. The presence of dog as a host is necessary in order to maintain a large population of $R$. sanguineus ticks, but cases of brown tick parasitizing humans are described more often [39-41]. The role of ticks in human cases of Q fever is considered negligible, because of the existence of other more common routes of infection. However, there are cases of human infections in the literature, connected with the tick bite, that indicate the possibility of humans acquiring infection this way [42-44].

\section{CONCLUSION}

The results obtained in this study place stray dogs into the group of animals that have an epidemiological significance in relation to $Q$ fever in Serbia. The high prevalence of C. burnetii in R. sanguineus, which is primarily a dog tick, indicates that the importance of dogs in the epidemiology of $\mathrm{Q}$ fever is much higher than it was expected. Further studies, which would include the detection of the pathogen in dogs, as well as serological response due to the $\mathrm{Q}$ fever agent, are necessary because they would provide a more detailed information about dogs as sentinel species for Q fever in Serbia. Due to the high prevalence of pathogens in ticks that primarily parasitize dogs, it is important, for pet owners, to point out the additional importance of protecting pets from ectoparasites, and for veterinarians to consider $Q$ fever in differential diagnostics, especially in cases of abortion in bitches and early death of pups. Considering that examined animals were stray dogs, further management of these animals is necessary in order to protect their health and welfare.

\section{Acknowledgement}

This research was funded by a grant from Ministry of Education, Science and Technological Development of the Republic of Serbia (Project number: TR31088). 


\section{Authors' contributions}

DB and NS performed molecular and parasitological study, data analysis and wrote the manuscript; DB, NS, and DM carried out the molecular genetic studies; VM collected the samples and assisted with the result analysis; KSD did the sequence analysis, critically revised the manuscript and helped to draft the manuscript; ST helped in the result interpretation, critically revised the manuscript; SR conceived and designed the study and together with ZK helped in the result interpretation, critically revised the manuscript. All authors read and approved the final manuscript.

\section{Declaration of conflicting interests}

The author(s) declared no potential conflicts of interest with respect to the research, authorship, and/or publication of this article.

\section{REFERENCES}

1. Babudieri B: Q fever: a zoonosis. Adv Vet Sci 1959, 5:81-154.

2. Scott GH, McCaul TF, Williams JC: Inactivation of Coxiella burnetii by Gamma Irradiation. Microbiology 1989, 135:3263-70.

3. Scott GH, Williams JC: Susceptibility of Coxiella burnetii to chemical disinfectants. Ann N Y Acad Sci 1990, 590:291-6.

4. Rousset E, Berri M, Durand B, Dufour P, Prigent M, Delcroix T, Touratier A, Rodolakis A: Coxiella burnetii shedding routes and antibody response after outbreaks of $\mathrm{Q}$ fever-induced abortion in dairy goat herds. Appl Environ Microbiol 2009, 75:428-33.

5. Maurin M, Raoult D: Q fever. Clin Microbiol Rev 1999, 12:518-53.

6. Rodolakis A: Q Fever in Dairy Animals. Ann N Y Acad Sci 2009, 1166:90-3.

7. Joulié A, Laroucau K, Bailly X, Prigent M, Gasqui P, Lepetitcolin E, Blanchard B, Rousset E, Sidi-Boumedine K, Jourdain E: Circulation of Coxiella burnetii in a naturally infected flock of dairy sheep: Shedding dynamics, environmental contamination, and genotype diversity. Appl Environ Microbiol 2015, 81:7253-60.

8. Marrie TJ: Epidemiology of Q fever. In: Q fever, Vol. I. Florida, USA: Boca Raton, CRC Press; 1990, 49-70.

9. Buhariwalla F, Cann B, Marrie TJ: A dog-related outbreak of Q fever. Clin Infect Dis 1996, 23:753-5.

10. Laughlin T, Waag D, Williams J, Marrie T: Q fever: from deer to dog to man. Lancet (London, England) 1991, 337:676-7.

11. Komiya T, Sadamasu K, Toriniwa H, Kato K, Arashima Y, Fukushi H, Hirai K, Arakawa Y: Epidemiological survey on the route of Coxiella burnetii infection in an animal hospital. J Infect Chemother 2003, 9:151-5.

12. Mantovani A, Benazzi P: The isolation of Coxiella burnetii from Rhipicephalus sanguineus on naturally infected dogs. J Am Vet Med Assoc 1953, 122:117-8. 
13. Smith DJW, Derrick EH: Studies in the Epidemiology of Q Fever. I. The Isolation of Six Strains of Rickettsia burneti from the Tick Haemaphysalis humerosa. Aust J Exp Biol Med Sci 1940, 18:1-8.

14. Philip CB: Observations on Experimental Q Fever. J Parasitol 1948, 34:457.

15. Duron O, Sidi-Boumedine K, Rousset E, Moutailler S, Jourdain E: The Importance of Ticks in Q Fever Transmission: What Has (and Has Not) Been Demonstrated? Trends Parasitol 2015, 31:536-52.

16. Eldin C, Mélenotte C, Mediannikov O, Ghigo E, Million M, Edouard S, Mege JL, Maurin M, Raoult D: From Q Fever to Coxiella burnetii Infection: a Paradigm Change. Clin Microbiol Rev 2017, 30:115-90.

17. Estrada-Peña A, Bouattour A, Camicas J, Walker AR: Ticks of Domestic Animals in the Mediterranean Region A guide to identification of species. 2004.

18. Berri M, Laroucau K, Rodolakis A: The detection of Coxiella burnetii from ovine genital swabs, milk and fecal samples by the use of a single touchdown polymerase chain reaction. Vet Microbiol 2000, 72:285-93.

19. Thompson JD, Higgins DG, Gibson TJ: CLUSTAL W: improving the sensitivity of progressive multiple sequence alignment through sequence weighting, position-specific gap penalties and weight matrix choice. Nucleic Acids Res 1994, 22:4673-80.

20. Duron O: The IS1111 insertion sequence used for detection of Coxiella burnetii is widespread in Coxiella-like endosymbionts of ticks. FEMS Microbiol Lett 2015, 362:fnv132.

21. Tomanović S, Chochlakis D, Radulović Ž, Milutinović M, Ćakić S, Mihaljica D, Tselentis Y, Psaroulaki A: Analysis Analysis of pathogen co-occurrence in host-seeking adult hard ticks from Serbia. Exp Appl Acarol 2013, 59:367-76.

22. Sukara R, Chochlakis D, Ćirović D, Penezić A, Mihaljica D, Ćakić S, Valčić M, Tselentis Y, Psaroulaki A, Tomanović S: Golden jackals (Canis aureus) as hosts for ticks and tick-borne pathogens in Serbia. Ticks Tick Borne Dis 2018. doi:10.1016/J.TTBDIS.2018.04.003.

23. Sprong H, Tijsse-Klasen E, Langelaar M, De Bruin A, Fonville M, Gassner F, Takken W, Van Wieren S, Nijhof A, Jongejan F, Maassen CB, Sholte EJ, Hovius JW, Emil Hovius JW, Spitalská E, Van Duynhoven YT: Prevalence of Coxiella burnetii in ticks after a large outbreak of Q Fever. Zoonoses Public Health 2012, 59:69-75.

24. Reye AL, Hübschen JM, Sausy A, Muller CP: Prevalence and seasonality of tick-borne pathogens in questing ixodes ricinus ticks from Luxembourg. Appl Environ Microbiol 2010, 76:2923-31.

25. Pluta S, Hartelt K, Oehme R, Mackenstedt U, Kimmig P: Prevalence of Coxiella burnetii and Rickettsia spp. in ticks and rodents in southern Germany. Ticks Tick Borne Dis 2010, $1: 145-7$.

26. Spitalská E, Kocianová E: Detection of Coxiella burnetii in ticks collected in Slovakia and Hungary. Eur J Epidemiol 2003, 18:263-6.

27. Barandika JF, Hurtado A, García-Esteban C, Gil H, Escudero R, Barral M, Jado I, Juste RA, Anda P, Gárcia-Pérez: Tick-borne zoonotic bacteria in wild and domestic small mammals in northern Spain. Appl Environ Microbiol 2007, 73:6166-71.

28. Barandika JF, Hurtado A, García-Sanmartín J, Juste RA, Anda P, García-Pérez AL: Prevalence of Tick-Borne Zoonotic Bacteria in Questing Adult Ticks from Northern Spain. Vector-Borne Zoonotic Dis 2008, 8:829-36. 
29. Bessas A, Leulmi H, Bitam I, Zaidi S, Ait-Oudhia K, Raoult D, Parola P Molecular evidence of vector-borne pathogens in dogs and cats and their ectoparasites in Algiers, Algeria. Comp Immunol Microbiol Infect Dis 2016, 45:23-8.

30. Andoh M, Andoh R, Teramoto K, Komiya T, Kaneshima T, Takano A, Hayashidani H, Ando S: Survey of Coxiella burnetii in Ticks Collected from Dogs in Japan. J Vet Med Sci 2013, 75:3-5.

31. Bolaños-Rivero M, Carranza-Rodríguez C, Rodríguez NF, Gutiérrez C, Pérez-Arellano J-L: Detection of Coxiella burnetii DNA in Peridomestic and Wild Animals and Ticks in an Endemic Region (Canary Islands, Spain). Vector-Borne Zoonotic Dis 2017, 17:630-4.

32. Toledo A, Jado I, Olmeda AS, Casado-Nistal MA, Gil H, Escudero R, Anda P: Detection of Coxiella burnetii in Ticks Collected from Central Spain. Vector-Borne Zoonotic Dis 2009, 9:465-8.

33. Satta G, Chisu V, Cabras P, Fois F, Masala G: Pathogens and symbionts in ticks: A survey on tick species distribution and presence of tick-transmitted micro-organisms in Sardinia, Italy. J Med Microbiol 2011, 60:63-8.

34. Spyridaki I, Psaroulaki A, Loukaides F, Antoniou M, Hadjichristodolou C, Tselentis Y: Isolation of Coxiella burnetii by a centrifugation shell-vial assay from ticks collected in Cyprus: Detection by nested polymerase chain reaction (PCR) and by PCR-restriction fragment length polymorphism analyses. Am J Trop Med Hyg 2002, 66:86-90.

35. Psaroulaki A, Hadjichristodoulou C, Loukaides F, Soteriades E, Konstantinidis A, Papastergiou P, Ioannidou MC, Tselentis Y: Epidemiological study of Q fever in humans, ruminant animals, and ticks in Cyprus using a geographical information system. Eur J Clin Microbiol Infect Dis 2006, 25:576-86.

36. Psaroulaki A, Chochlakis D, Angelakis E, Ioannou I, Tselentis Y: Coxiella burnetii in wildlife and ticks in an endemic area. Trans R Soc Trop Med Hyg 2014, 108:625-31.

37. Dantas-Torres F: The brown dog tick, Rhipicephalus sanguineus (Latreille, 1806) (Acari: Ixodidae): From taxonomy to control. Vet Parasitol 2008, 152:173-85.

38. Little SE, Hostetler J, Kocan KM: Movement of Rhipicephalus sanguineus adults between cohoused dogs during active feeding. Vet Parasitol 2007, 150:139-45.

39. Estrada-Peña A, Jongejan F: Ticks feeding on humans: A review of records on humanbiting Ixodoidea with special reference to pathogen transmission. Exp Appl Acarol 1999, 23:685-715.

40. Demma LJ, Traeger MS, Nicholson WL, Paddock CD, Blau DM, Eremeeva ME, Dasch GA, Levin ML, 442 Singleton J Jr, Zaki SR, Cheek JE, Swerdlow DL, McQuiston JH: Rocky Mountain Spotted Fever from an Unexpected Tick Vector in Arizona. N Engl J Med 2005, 353:587-94.

41. Dantas-Torres F, Figueredo LA, Brandão-Filho SP: Rhipicephalus sanguineus (Acari: Ixodidae), the brown dog tick, parasitizing humans in Brazil. Rev Soc Bras Med Trop 2006, 39:64-7.

42. Beaman MH, Hung J: Pericarditis associated with tick-borne Q fever. Aust N Z J Med 1989, 19:254-6.

43. Rolain JM, Gouriet F, Brouqui P, Larrey D, Janbon F, Vene S, Jarnestrom V, Raoult D: Concomitant or Consecutive Infection with Coxiella burnetii and Tickborne Diseases. Clin Infect Dis 2005, 40:82-8.

44. Nett RJ, Book E, Anderson AD: Q Fever with unusual exposure history: a classic presentation of a commonly misdiagnosed disease. Case Rep Infect Dis 2012, 2012:916142. 


\title{
MOLEKULARNI DOKAZ PRISUSTVA UZROČNIKA KJU GROZNICE COXIELLA BURNETII U IKSODIDNIM KRPELJIMA SAKUPLJENIM SA NEVLASNIČKIH PASA U BEOGRADU (SRBIJA)
}

\author{
BOGUNOVIĆ Danica, STEVIĆ Nataša, SIDI-BOUMEDINE Karim, \\ MIŠIĆ Dušan, TOMANOVIĆ Snežana, KULIŠIĆ Zoran, MAGAŠ Vladimir, \\ RADOJIČIĆ Sonja
}

Kju groznica je zoonozno oboljenje koje izaziva Coxiella burnetii, gram-negativni kokobacil, čije je prisustvo zabeleženo kod velikog broja životinjskih vrsta, prvenstveno domaćih preživara, ali i kod divljih sisara, kućnih ljubimaca, ptica, reptila, artropoda (naročito krpelja) i ljudi. Iako se kontakt sa domaćim životinjama u ruralnim sredinama smatra najčešćim uzrokom oboljenja ljudi, skorija istraživanja su pokazala da je uloga kućnih ljubimaca u epidemiologiji Kju groznice značajno porasla. Iako je primarni put infekcije inhalacija, pretpostavlja se da među životinjama infekcija cirkuliše preko krpelja i da su krpelji odgovorni za heterospecijsko prenošenje, kao i za prostorno širenje uzročnika među kičmenjacima. Cilj ovog istraživanja je bio da se ustanovi prisustvo i prevalencija C. burnetii u krpeljima poreklom sa pasa lutalica, kao i da se ispita rasprostranjenost vrsta krpelja koje parazitiraju na psima na teritoriji Beograda. Za otkrivanje DNK C. burnetii u krpeljima korišćen je PCR protokol koji cilja IS1111 ponavljajući region sličan transpozonu, a rezultati su potvrđeni analizom nukleotidnih sekvenci. Sakupljeno je ukupno 316 krpelja sa 51 psa lutalice - 40 ženki (78.43\%) i 11 mužjaka (21.57\%). Identifikovane su tri vrste krpelja: Rhipicephalus sanguineus $(72.15 \%)$, Ixodes ricinus (27.53\%) i Dermacentor reticulatus (0.32\%). Od ukupno 316 ispitanih krpelja, DNK C. burnetii je otkrivena samo u braon psećem krpelju R. sanguineus, sa ukupnom prevalencijom 10.53\% (24/228). Visoka prevalencija C. burnetii u R. sanguineus, koji je primarno krpelj pasa, ukazuje na značaj pasa u epidemiologiji Kju groznice na teritoriji Beograda. 